J. Clin. Chem. Clin. Biochem.

Vol. 26,1988 , pp. $69-74$

(C) 1988 Walter de Gruyter \& Co.

Berlin - New York

\title{
Direct Single-Reagent Fluorescence Polarisation Immunoassay for Valproic Acid in Serum
}

\author{
By A. M. Sidki, Kristina Staley, H. Boyes, J. Landon and A. H. Williams \\ Department of Chemical Pathology, St. Bartholomew's Hospital, London, U. K.
}

(Received September 7, 1987/January 8, 1988)

\begin{abstract}
Summary: A fluorescence polarisation immunoassay for quantitating serum concentrations of valproic acid was developed and validated. Its low molecular weight and lack of structural features caused difficulties in producing suitable antibodies. However, success was achieved using 2-propyl-6-aminohexanoic acid to make the fluorescein-labelled drug and two immunogens, the first using glutaraldehyde to link the drug derivative to keyhole limpet haemocyanin, and the second by carbodiimide activation of cellulose hydroxyl groups and coupling them to the drug derivative and killed Mycobacteria. It was found that both immunogens produced a good antibody response in sheep. The antibodies were highly specific and the assay results correlated well with an in-house gas-liquid chromatographic method.
\end{abstract}

\section{Introduction}

During recent years, valproic acid has become a firstchoice drug in the treatment of most types of epilepsy. There is increasing interest in its quantitative measurement in plasma or serum for the detection of poor compliance and because of the great individual differences in dosage requirements to achieve therapeutic concentrations $(1,2)$. Various assay methods have been introduced including gas-liquid chromatography (3), high-performance liquid chromatography (4) and immunoassays (5). Enzymeimmunoassays and fluorescence polarisation immunoassays are now the most widely used in therapeutic drug monitoring due to their simplicity, and the availability of automated or semiautomated instruments and commercial kits (6). In addition to their speed and high sample throughput these methods are reliable and specific and the results obtained correlate well with chromatographic methods (7).

It proved difficult to raise suitable antibodies against valproic acid because of its small size and structural simplicity. Coupling the drug directly to keyhole limpet haemocyanin through its free carboxyl group, or coupling dipropyl malonic acid (2-carboxy valproic acid) to the carrier protein proved unsuccessful; both resulted in the production of ovine antibodies able to bind the fluorescein-labelled derivative prepared through the same functional group, but not the unlabelled drug. However, a suitable antibody response is produced in sheep immunised with an immunogen prepared by coupling the hydrocarbon chain of the molecule, via a suitable functional group, to keyhole limpet haemocyanin, and the resulting antisera used with a fluorescein-labelled derivative prepared through the same route. These reagents were employed to develop the present single-reagent fluorescence polarisation immunoassay (FPIA) for the direct determination of valproic acid in serum.

\section{Materials and Methods}

\section{Reagents}

Sodium valproate was a gift from Reckitt and Colman, Kingston-upon-Hull, U. K. Valproate metabolites were gifts from Dr. $H$. Schafer, Desitin-Werk Carl Klinke GmbH Hamburg, F. R. G. and from Sanofi UK Ltd, Manchester, U. K. Fluorescein isothiocyanate isomer 1 (FITC), Sigmacell type 20, and most chemicals used in synthesis and cross-reactivity cxperiments were obtained from Sigma, Poole. Dorset. U. K.: keyhole 
limpet haemocyanin from Calbiochem-Behring, San Diego, CA 92112, U.S.A.; silica gel thin-layer chromatography (TLC) plates (type PLK5F) from Whatman, Maidstone, Kent, U.K.; triethylamine from Koch-Light, Colnbrook, Bucks, U. K.; Triton $X-100$ surfactant, sodium azide, sodium lauryl sulphate and all organic solvents ("Analar" grade) from BDH Chemicals, Poole, Dorset, U.K.; and pooled normal human serum from ILS, London ECI, U.K. Other drugs employed in the specificity studies were donated by their respective U.K. distributors.

\section{Assay standards}

A $1 \mathrm{~g} / \mathrm{l}$ solution of valproic acid in methanol was prepared and added to drug-free pooled normal human serum to obtain the following concentrations: $10,20,50,100$, and $200 \mathrm{mg} / \mathrm{l}$.

\section{Patients' specimens}

Serum samples from patients receiving valproic acid, with or without other antiepileptic drugs, were obtained and assayed by a gas-liquid chromatographic method (8).

\section{Diluent buffer}

Sodium phosphate buffer (100 mmol/l, pH 7.5) containing per litre, $1.0 \mathrm{mg}$ sodium lauryl sulphate, $2.2 \mathrm{mg}$ Triton $\mathrm{X}-100$ and $1 \mathrm{~g}$ of sodium azide as an antibacterial agent.

\section{Assay tubes}

Disposable $50 \times 10 \mathrm{~mm}$ round glass cuvettes (no. 9518), from Abbott Diagnostic Division, Basingstoke, Hampshire, U.K.

\section{Polarisation fluorometer}

A Model 4000 polarisation fluorometer (SLM Instruments, Urbana, IL 61801) was employed, as described previously (8), except that the sample compartment was fitted with an adaptor to accept the cylindrical cuvettes.

\section{Preparation procedures \\ 2-Propyl-6-aminohexanoic acid}

Sodium hydride $(0.43 \mathrm{~g}, 10.7 \mathrm{mmol})$ was dissolved in $30 \mathrm{ml}$ of dry dimethyl formamide and reacted with $2 \mathrm{ml}(9.7 \mathrm{mmol})$ of diethylpropylmalonate. After $30 \mathrm{~min}$ with continuous stirring, $2.7 \mathrm{~g}(9.7 \mathrm{mmol})$ of $\mathrm{N}$-(4-bromobutyl) phthalimide was added and refluxed for $1.5 \mathrm{~h}$. The reaction mixture was diluted with ether, washed several times with water, dried over magnesium sulphate and the solvent evaporated under reduced pressure to yield a yellow oil. This was purified by flash column chromatography (petroleum ether/diethyl ether, $2+1$ by vol) to obtain $3.6 \mathrm{~g}(91 \%$ yield) of a white solid diethyl-(4-N-butyl phthalimide)propyl malonate. This diester $(0.85 \mathrm{~g}, 2.1 \mathrm{mmol})$ and 0.5 $\mathrm{ml}(10 \mathrm{mmol})$ of hydrazine were then dissolved in $30 \mathrm{ml}$ methanol and refluxed for $4 \mathrm{~h}$. After removing the solvent, the residue was dissolved in $1 \mathrm{~mol} / 1 \mathrm{HCl}$, washed with chloroform, made alkaline with $2 \mathrm{~mol} / \mathrm{l} \mathrm{NaOH}$ and extracted with chloroform. The organic phase was washed with water, dried over magnesium sulphate and the solvent evaporated under vacuum to yield an oil which was dissolved in $15 \mathrm{ml}$ of $6 \mathrm{~mol} / \mathrm{l} \mathrm{HCl}$ and refluxed overnight. The reaction mixture was neutralised, the water evaporated and the residue extracted with methanol. Upon filtration and removal of the solvent, $0.23 \mathrm{~g}$ of a white solid (2-propyl-6-aminohexanoic acid) was obtained (fig. 1).<smiles>CCCCC(CCC)C(=O)O</smiles>

(a)<smiles>CCCC(CCC)(C(=O)O)C(=O)O</smiles>

(b)<smiles>CCCC(CC(Cl)Cl)C(=O)O</smiles>

Fig. 1. Structural formulae of (a) valproic acid, (b) dipropyl malonic acid, and (c) 2-propyl-6-amino hexanoic acid.

\section{Valproate immunogen I}

2-Propyl-6-aminohexanoic acid (50 $\mathrm{mg}, 0.3 \mathrm{mmol}$ ) was reacted with $1 \mathrm{ml}$ of $50 \mathrm{~g} / 1$ glutaraldehyde $(0.6 \mathrm{mmol})$ in $1 \mathrm{ml}$ of $1 \mathrm{~mol} / \mathrm{l}$ acetate buffer pH 7.0. After $5 \mathrm{~min}$ of continuous mixing, this was added to a solution of $60 \mathrm{mg}$ keyhole limpet haemocyanin in $5 \mathrm{ml}$ acetate buffer and stirred for $30 \mathrm{~min}$. Then a solution of $100 \mathrm{mg}$ sodium borohydride in $2 \mathrm{ml}$ distilled water was added; the reaction mixture stirred for $15 \mathrm{~min}$; transferred to a dialysis bag and dialysed for 3 days against three changes of 5 litres of phosphate buffered saline $(50 \mathrm{mmol} / \mathrm{l}, \mathrm{pH} 7.4)$. When lyophilised, it yielded $76 \mathrm{mg}$ of the conjugate.

\section{Valproate immunogen II}

Carbonylimidazole $(30 \mathrm{mg})$ was added to a suspension of Sigmacell Type 20 cellulose in $2 \mathrm{ml}$ of dry acetone and stirred for $1 \mathrm{~h}$ at room temperature. Then a solution of 2-propyl-6-aminohexanoic acid $(50 \mathrm{mg}, 0.3 \mathrm{mmol})$ and triethylamine $(50 \mu \mathrm{l})$ in $1 \mathrm{ml}$ of acetone was added. After stirring for $1 \mathrm{~h}, 30 \mathrm{mg}$ of a suspension of killed Mycobacteria in water was added. The reaction mixture was stirred overnight, dialysed as above and lyophilised to yield $146 \mathrm{mg}$ of the conjugate.

\section{Fluorescein tracer}

Ten $\mathrm{mg}(0.06 \mathrm{mmol})$ of 2-propyl-6-aminohexanoic acid and $10 \mathrm{mg}(0.03 \mathrm{mmol})$ of fluorescein isothiocyanate isomer- 1 were dissolved in $2 \mathrm{ml}$ methanol containing $1 \mathrm{ml} / \mathrm{l}$ of triethylamine. After stirring for $2 \mathrm{~h}$, in the dark, at ambient temperature, the solution was acidified with $1 \mathrm{~mol} / \mathrm{l} \mathrm{HCl}$ and then filtered. The precipitate obtained was dissolved in methanol and purified by thin-layer chromatography, using methylene chloride/methanol $\left(1+1\right.$ by vol) to separate a major band $\left(R_{f} 0.3\right)$. The band was scraped from the plate, extracted with methanol and stored at $-20^{\circ} \mathrm{C}$. The concentration of the fluorescein tracer was estimated spectrophotometrically as described previously (10).

\section{Anti-valproic acid anti-sera}

Three ewes were immunised with immunogen İ (no. 101, 102, and 103) and an additional 3 ewes with immunogen II (no. 14, $15,16)$ according to a protocol described elsewhere (10). 


\section{Procedures}

\section{Gas-liquid chromatography procedures}

A Pye Unicam series 304 instrument linked to a Hewlett Packard $3380 \mathrm{~A}$ integrator was used for routine determination of valproic acid in serum samples following an established method (8). Briefly, each serum sample was acidified with $1 \mathrm{~mol} / 1 \mathrm{HCl}$ and added to a glass tube containing benzyl alcohol as internal standard. Then the sample was extracted into $1 \mathrm{ml}$ chloroform of which $5 \mu \mathrm{l}$ was injected directly onto a column packed with $100 \mathrm{~g} / \mathrm{l}$ diethylglycol succinate on Chromosorb W. H.P. 100/ 120 mesh.

\section{Fluorescence polarisation immunoassay (FPIA) procedures}

Premixed reagent: A solution of fluorescein labelled valproate in assay buffer was prepared at a concentration of $30 \mathrm{nmol} / \mathrm{l}$. To this was added anti-valproate anti-serum (pre-diluted 100fold) in the ratio $2: 1$. The reagent was then stored at $4^{\circ} \mathrm{C}$ in the dark until required.

Assay protocol: Assays were performed at room temperature in duplicate. To $25 \mu$ l of diluted serum standard or sample (prediluted 50 -fold in diluent buffer) was added $1.5 \mathrm{ml}$ of the premixed reagent in the glass cuvette. The cuvettes were vortex mixed, incubated for $10 \mathrm{~min}$ before fluorescence polarisation was measured.

\section{Results}

Characterisation of the valproate immunogens

Immunogens I and II were hydrolysed by refluxing with $10 \mathrm{ml}$ of dilute $\mathrm{HCl}$ for $1 \mathrm{~h}$. Upon diluting the product in the assay buffer and measuring the concentration of valproate by the present assay, a ratio of "valproic acid equivalent" to the carrier was obtained: $0.7 \mathrm{mmol} / \mathrm{g}$ (2300:1 in molar terms) for immunogen I and $0.03 \mathrm{mmol} / \mathrm{g}$ for immunogen II.

\section{Anti-valproate anti-sera}

All sheep produced antibodies that bound valproic acid but the antisera varied significantly in their titres. The immunoglobulin fraction of each serum and of a non-immunised sheep serum were obtained by conventional sodium sulphate precipitation (11) and doubly diluted in diluent buffer. Antibody dilution curves were constructed by adding $1 \mathrm{ml}$ aliquots of these dilutions to $0.5 \mathrm{ml}$ of the fluorescein tracer (30 nmol/1), measuring fluorescence polarisation and making a background correction. Figure 2 shows such curves for the most responsive sheep to each immunogen (no. 102 and 14) and for a non-immunised sheep. The antiserum from sheep 102 was used in all further studies.

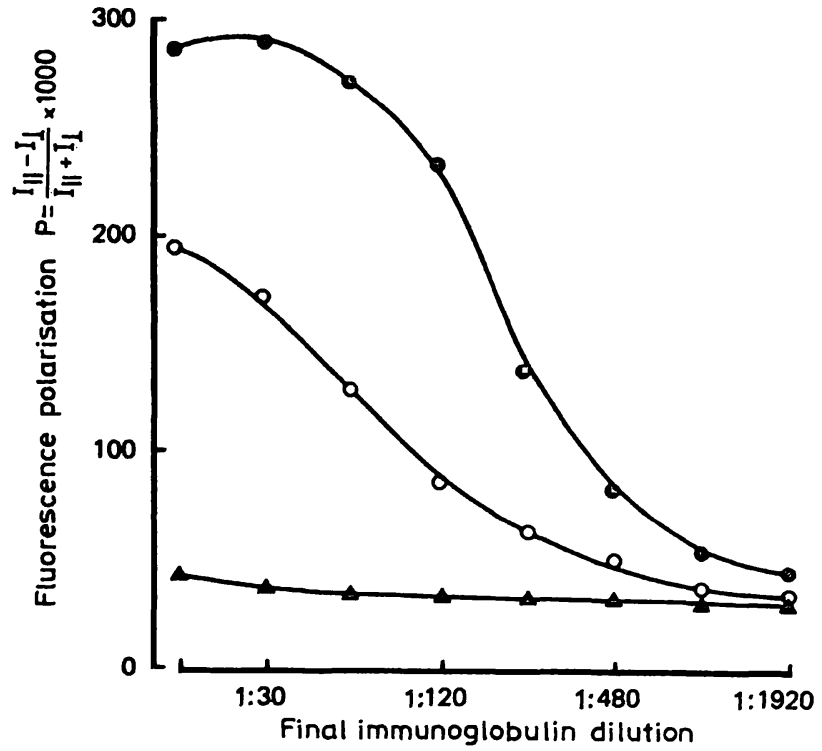

Fig. 2. Dilution curves of the immunoglobulin fractions of antivalproic acid antisera obtained from the second bleed of sheep $102(0)$, the eighth bleed of sheep G14 (0) and a non-immunised sheep serum $(\mathbf{A})$.

The polarisation of fluorescence $(\mathrm{P})$ is defined as: $P=\frac{I_{\| 1}-I_{\perp}}{I_{\|}-I_{\perp}}$ where

$I_{11}=$ intensity of the fluorescence when the exciting light is vertically polarised (parallel to the direction of the electric vector of the exciting wave)

$I_{\perp}=$ intensity of the fluorescence when the exciting light is horizontally polarised (perpendicular to the direction of the electric vector of the exciting wave)

As a quotient, $\mathrm{P}$ has the unit 1 (one, dimension-less).

\section{Optimisation of assay conditions}

The presence of albumin and other serum proteins increased the fluorescence polarisation signal due to non-specific binding with the fluorescein tracer. This was abolished by incorporating $1.0 \mathrm{mg} / \mathrm{l}$ of sodium lauryl sulphate as a blocking agent in assay diluent buffer. Triton X-100 was added in equimolar concentration $(2.2 \mathrm{mg} / \mathrm{l})$ in the assay buffer to overcome the antigen-antibody inhibition effect caused by sodium lauryl sulphate (12).

\section{Assay kinetics}

\section{Association kinetics}

The association of the fluorescein tracer with the valproate antibodies was investigated by obtaining serial polarisation readings after adding $0.5 \mathrm{ml}$ of tracer $(30 \mathrm{nmol} / \mathrm{l})$ to $1 \mathrm{ml}$ of the antiserum (diluted 100-fold), which were plotted against time on linear paper. The polarisation readings increased rapidly and reached a plateau within $45 \mathrm{~s}$. 


\section{Dissociation kinetics}

The rate of dissociation was investigated as previously described (6). Two populations of antibody were found, one with a polarisation half life of about $57 \mathrm{~s}$, and the other, a faster dissociating antibody, with a half-life of about $24 \mathrm{~s}$. Both constitute a substantial proportion of the total antibody populations.

\section{Incubation time}

Each standard was assayed and polarisation readings taken at timed intervals. The assay reached equilibrium after $10 \mathrm{~min}$ and the polarisation readings were stable for at least $45 \mathrm{~min}$.

\section{Standard curve}

A typical standard curve (fig. 3) was obtained using $25 \mu \mathrm{l}$ of buffer or serum standard (prediluted 50 -fold) which covered the clinically relevant range for valproate.

\section{Assay validation}

\section{Sensitivity}

The sensitivity of the assay was determined by the Rodbard method (13). The minimal detectable concentration of valproic acid was $1.9 \mathrm{mg} / 1$ and the minimal detectable dose was $0.95 \mathrm{ng}$ per tube.

\section{Imprecision}

Three selected samples of patients' sera were each assayed ten times in one assay, and gave mean results of 37,90 , and $132 \mathrm{mg}$ valproic acid per litre with CVs of $3.7 \%, 3.5 \%$ and $3.8 \%$ respectively. The same samples were assayed on ten separate occasions and gave between-assay CVs of $5.9 \%, 4.1 \%$, and $3.1 \%$ respectively. A precision profile was calculated using the Edinburgh immunoassay program (14) from the data collected from a standard curve and the simultaneous assay of 50 patients' samples. Within the boundaries of the standard curve the CVs were all below $10 \%$ (fig. 4).

\section{Analytical recovery}

Valproic acid was added at concentrations of 10,20 and $50 \mathrm{mg} / 1$ to four patients' samples containing valproic acid in concentrations ranging from 0 to 125 $\mathrm{mg} / \mathrm{l}$. Average analytical recovery was $99.6 \%, 97.2 \%$ and $95.0 \%$ respectively.

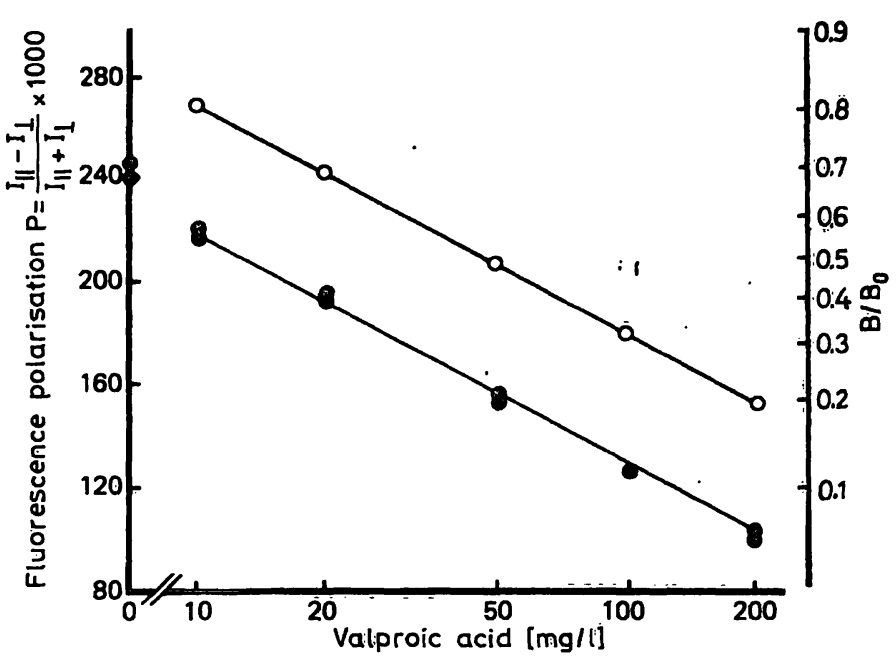

Fig. 3. Standard curves for valproic acid obtained by fluorescence polarisation (o) and from the Logit-Log transformation (0).

For further explanations see fig. 2.

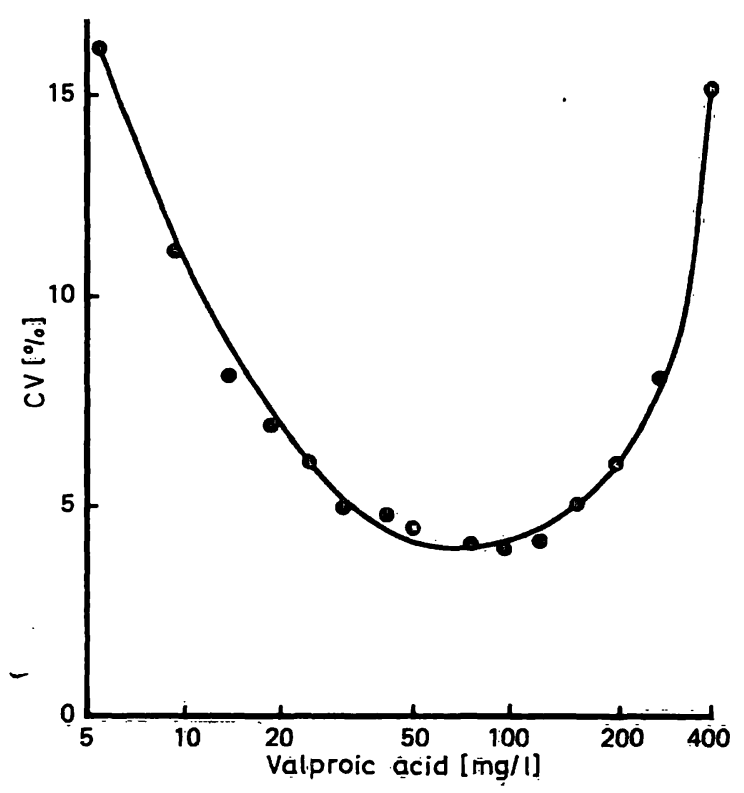

\section{Linearity and parallelism}

The standard curve for valproic acid exhibited good linearity (fig. 3). When a patient's serum containing a high concentration of valproic acid $(130 \mathrm{mg} / \mathrm{l})$ was diluted 2-, 4-, 8-, and 16-fold in diluent buffer, the values obtained were linear and parallel to the normal standard curve.

The results obtained from a typical standard curve were processed by the Logit=Log program (15) converting polarisation readings to $B / B_{0}$ values. $A$ straight line was obtained which was parallel to the normal standard curve (fig. 3). 
Zenon Schneider $\cdot$ AndrzejStroiński Comprehensive $B_{12}$

\section{Chemistry $\cdot$ Biochemistry}

Nutrition - Ecology $\cdot$ Medicine

$1987.18 \mathrm{~cm} \times 26 \mathrm{~cm}$. XII, 409 pages,

numerous illustrations.

Hardcover. DM 290,-; approx. US \$ 160.00 ISBN $311008239 \mathrm{X}$

This book is addressed to clinicians and advanced students in different areas such as chemists, biochemists, pharmacologists, nutritionists, animal breeders, ecologists and marine biologists who wish to extract essential information on particular aspects of vitamin $\mathrm{B}_{12}$.

Most of the data presented are accompanied by references to the original literature and are preceded by a brief and comprehensive introduction.

Some techniques which at present are of interest to a wider group of researchers such as immobilization of vitamin $B_{12}$ on supports, methods of $B_{12}$ assay and biological or chemical synthesis of various $B_{12}$ analogues are described in detail.

\section{Contents in brief}

Historical outline - Nomenclature of Corrinoids - Chemistry of Cobalamin and Related Compounds - Biosynthesis of Vitamin $B_{12}$. Purification and Estimation of Vitamin $B_{12}$. The Occurrence and Distribution of Corrinoids - Cobamide Dependent Enzymes · Non-Enzymatic Vitamin $B_{12}$ Binding Proteins in Man and Animals - Medical Aspects of Vitamin $B_{12} \cdot$ Index of Species · Subject Index

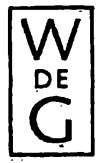

de Gruyter · Berlin · New York

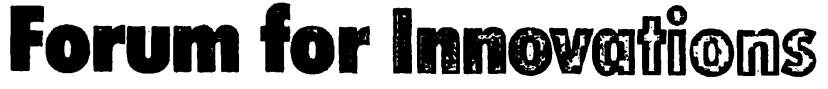
for Biochemiecel 메 "

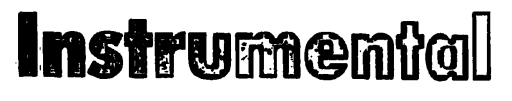
Anculysisis

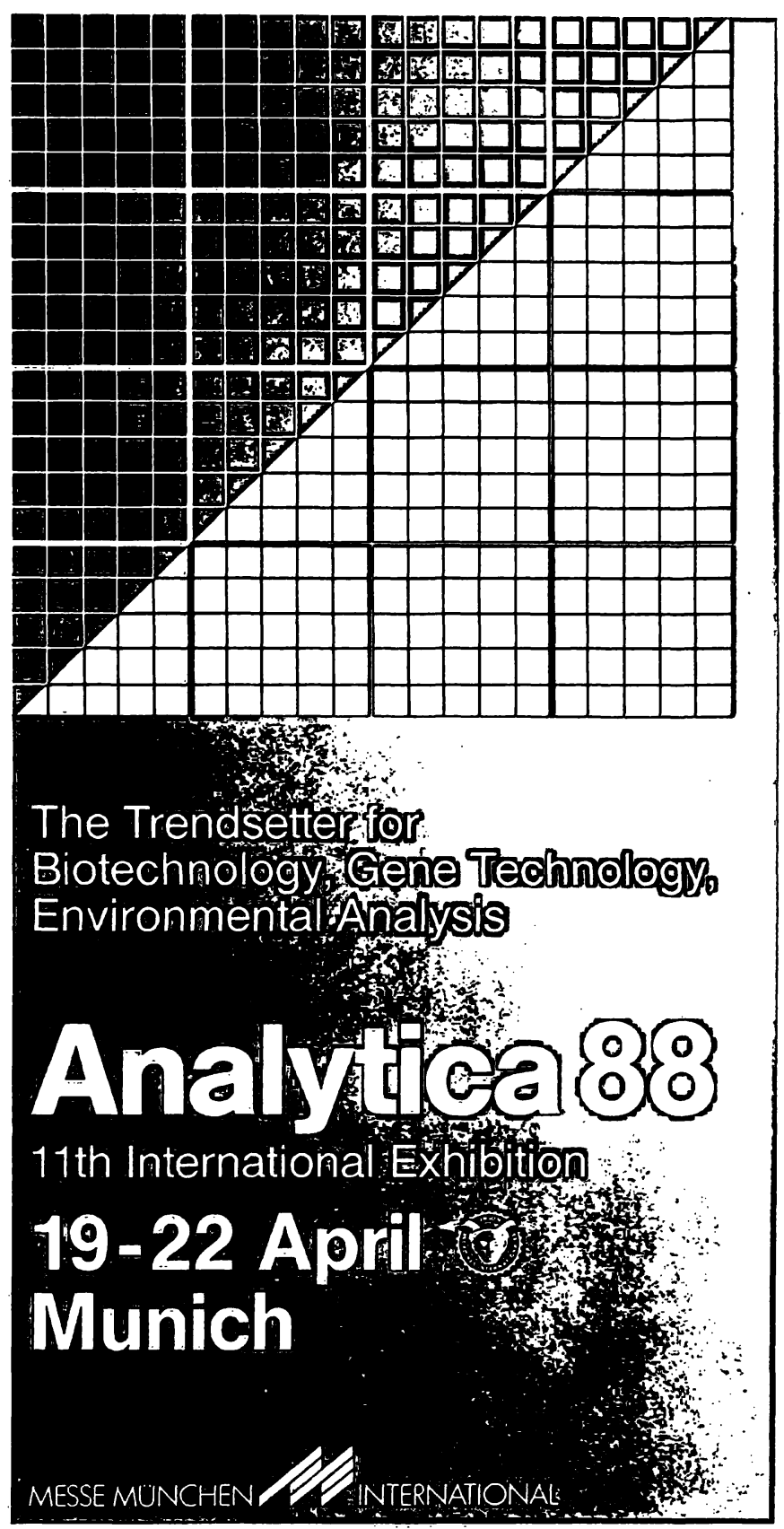

Coupon - Analytica 88

Please send further information on Analytica.

Name

Street/P.O.Box

Town, Postal code

Country

Organizer: Münchener Messe- und Ausstellungsgesellschaft mbH, Postfach 1210 09, D-8000 München 12,

Telephone (89) 51 07-0, Telex 5212086 ameg d. 


\section{de Fruyter References}

\section{NEW, COMPLETELY REVISED THIRTEENTH EDITION}

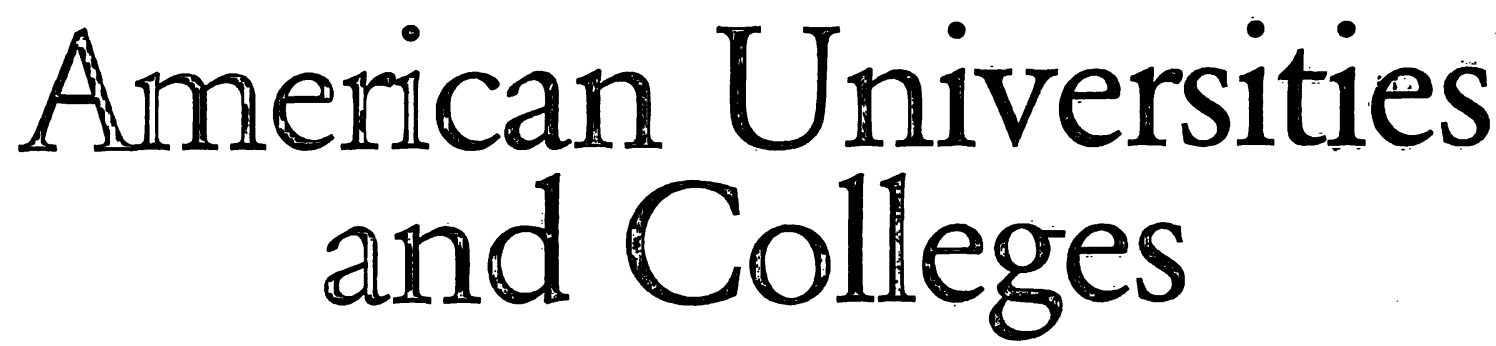

Produced in collaboration with the American Council on Education

1987. $21 \times 27.5 \mathrm{~cm}$. XX, 2040 pages. With numerous charts and tables. Cloth DM298,- ISBN 3110109026

American Universities and Colleges is published every four years. We invite standing orders.

Based on a new survey begun in September 1986, this completely updated and expanded edition of American Universities'and Colleges continues the tradition of being the foremost reference book on postsecondary education in the United States. Prepared in collaboration with the American Council on Education, the major coordinating body of higher education, the revised Thirteenth Edition provides the most comprehensive collection of information on accredited institutions offering baccalaureate degrees and above.

The Thirteenth Edition is enlarged both in the number of institutions represented and the amount of information provided. Over 1,900 institutions are covered, including 125 new institutions recently accredited.

American Universities and Colleges provides both the essential statistical data (tuition, room, board, admissions requirements, financial aid, enrollments, etc.) and all the other information equally important to decision making (student life, library holdings, physical plant, accelerated and study-abroad programs, etc.). A full section is devoted to the foreign student in U.S. institutions. Included is a list of overseas offices with counseling services on study in the U.S., plus a number of tables dealing with various aspects of foreign student enrollments from 1954-55 to 1985-86.

Another section deals with professional education in the U.S., using nearly 40 subject areas to discuss the institutions offering professional programs, admission and degree requirements, and licensing and certification programs. Other sections deal with such diverse topics as the history of higher education in the U.S. and the academic costume code.

\section{From reviews of the Twelfth Edition:}

"To sum up these five guides ... no high school, public, or academic library reference collection is adequate without AUC."

Choice

"The new edition continues the tradition of completeness ... No other general purpose college guide offers similar coverage ... belongs in every academic, public, and high school library, for it provides perspectives on colleges other guides do not even consider."

Wilson Library Bulletin

\section{de Gruyter · Berlin · New York}




\section{Specificity}

\section{Antibody specificity}

To assess the specificity of the anti-valproate antibodies, the following chemicals, sharing some structural similarity to valproic acid, were tested for their crossreactivity at a concentration of $1 \mathrm{~g} / \mathrm{l}$; ethanoic acid, propanoic acid, butanoic acid, pentanoic acid, hexanoic acid, heptanoic acid, norvaline, valine, amino$n$-valeric acid, ornithine, valeric acid ethyl ester and benzoyl amino- $n$-valeric acid. The aliphatic carboxylic acids did cross-react, but not significantly - all less than $2 \%$. All other analytes showed zero cross-reactivity, demonstrating the high specificity of the antibodies produced.

\section{Clinical specificity}

The cross-reactivity of the main metabolites of valproate (16) were determined at a concentration of $1 \mathrm{~g} / \mathrm{l}$, relative to valproic acid. Those which crossreacted significantly at this level were further assessed by Abraham's method (17). The results are shown in table 1 . None cross-reacted to an extent likely to cause

Tab. 1. Cross-reactivity of valproic acid metabolites

\begin{tabular}{|c|c|c|}
\hline Compound & $\begin{array}{l}\text { \% Cross- } \\
\text { reactivity } \\
\text { by Abraham's } \\
\text { method }\end{array}$ & $\begin{array}{l}\% \text { Cross- } \\
\text { reactivity } \\
\text { at } 1 \mathrm{~g} / 1\end{array}$ \\
\hline $\begin{array}{l}\text { (1) 2-propyl-2-pentenoic acid } \\
\text { (2-en valproic acid) }\end{array}$ & 18.3 & 15.0 \\
\hline $\begin{array}{l}\text { (2) 2-propyl-4-pentenoic acid } \\
\text { (4-en valproic acid) }\end{array}$ & 36.7 & 25.0 \\
\hline $\begin{array}{l}\text { (3) 3-hydroxy-2-propyl } \\
\text { pentanoic acid } \\
\text { (3-OH valproic acid) }\end{array}$ & - & $<1.0$ \\
\hline $\begin{array}{l}\text { (4) 4-hydroxy-2-propyl } \\
\text { pentanoic acid } \\
\text { (4=OH valproic acid) }\end{array}$ & - & $1.0-2.0$ \\
\hline $\begin{array}{l}\text { (5) 5-hydroxy-2-propyl } \\
\text { pentanoic acid } \\
\text { (5-OH valproic acid) }\end{array}$ & 22.2 & 20.0 \\
\hline $\begin{array}{l}\text { (6) 3-oxo 2-propyl pentanoic } \\
\text { acid } \\
\text { (3-keto valproic acid) }\end{array}$ & - & $<1.0$ \\
\hline $\begin{array}{l}\text { (7) 2-propyl-4-methyl } \\
\text { butyrolactone } \\
\text { (4-hydroxyvalproic acid } \\
\text { lactone) }\end{array}$ & - & 1.0 \\
\hline $\begin{array}{l}\text { (8) 2-propyl pentyrolactone } \\
\text { (5-hydroxyvalproic acid } \\
\text { lactone) }\end{array}$ & - & $1: 0-2.0$ \\
\hline (9) 2-n-propyl glutaric acid & - & $<1: 0$ \\
\hline
\end{tabular}

inaccuracy in the assay of patients' samples. Other antiepileptic drugs and their major metabolites showed no cross-reaction when tested at concentrations up to $1 \mathrm{~g} / \mathrm{l}$.

\section{Accelerated stability study}

A bulk $(50 \mathrm{ml})$ of the premixed reagent was prepared and after overnight incubation, a standard curve was obtained. The reagent was then stored in the dark at $37^{\circ} \mathrm{C}$ for a week, after which a comparable standard curve was obtained, indicating that the single reagent should be stable for a year at $4{ }^{\circ} \mathrm{C}(18)$.

Correlation with gas-liquid chromatography method

Results of the assay of 46 patients' serum samples by this assay (y) and by the chromatographic technique (x) were related by the regression line $y=1.0 x+2.9$ $(r=0.99)$ which was calculated assuming that the two methods have equal precision characteristics (19).

\section{Discussion}

We describe another "single-reagent FPIA" utilizing the short dissociation half-lives of most hapten : antibody complexes $(6,18)$. For such assays to be feasible, one requires antiserum which contains a substantial population of fast dissociating antibodies. In spite of the initial difficulties encountered in raising antibodies to such a small molecule, we were eventually successful in producing an antiserum which contains a substantial proportion of fast dissociating antibodies. These antibodies consist of two major populations with polarisation half-lives of $24 \mathrm{~s}$ and $57 \mathrm{~s}$, which have allowed us to develop the present single-reagent FPIA for valproic acid.

The additional advantage of such assays is the longterm stability of the premixed reagent as shown by the accelerated stability study. The premixed reagent was stable and gave comparable results when stored at $37^{\circ} \mathrm{C}$ for 1 week which implies one year's stability at $4{ }^{\circ} \mathrm{C}(18)$.

In raising antisera to valproic acid two immunogens were prepared by coupling 2-propyl-6-aminohexanoic acid to two different carrier molecules. The high valproate/keyhole limpet haemocyanin incorporation ratio in immunogen I may have resulted in the greater antibody response in the immunised sheep, as com- 
pared with the second immunogen (valproate/Sigmacell-Mycobacteria conjugate).

The specificity studies show that highly specific antibodies were produced, with, as expected, optimum selectivity for the carboxylic acid group of valproic acid. The introduction of a hydroxyl or a oxo group close to the carboxylic acid grouping prevents antibody binding, but a hydroxyl group further along the molecule is less effective and 5-hydroxy valproic acid therefore shows greater cross-reactivity than its 4 hydroxy and 3-hydroxy counterparts. The presence of an additional carboxyl group in 2- $n$-propyl glutaric acid, although at the far end of the molecule, prevented antibody binding presumably by modifying the polarity, electron density, and the effective charges of the molecule, thereby interferring with the forces involved in antigen-antibody binding.

\section{References}

1. Schobben, F., Kleijn Van der, E. \& Vree, T. B. (1980) Ther. Drug Monit. 2, 61-71.

2. Bruni, J. \& Wilder, J. (1979) Arch. Neurol. 36, 393-398.

3. Jakobs, C., Bojasch, M. \& Hanefeld, F. (1978) J. Chromatogr. Biomed. Appl. 146, 494-497.

4. Gupta, R. N., Keane, P. M. \& Gupta, M. L. (1979) Clin. Chem. 25, 1984-1985.

5. Elyas, A. A., Goldberg, V. D., Ratnaraj, N. \& Lascelles, P. T. (1980) Ann. Clin. Biochem. 17, 307-310.

6. Colbert, D. L., Smith, D. S., Landon, J. \& Sidki, A. M. (1984) Clin. Chem. 30, 1765-1769.

7. Jolley, M. E. (1981) J. Anal. Toxicol. 5, 236-240.

8. Fullinfaw, R. O. \& Marty, J. J. (1981) Clin. Chem. 27, 1776 (Letter).

9. Sidki, A. M., Pourfarzaneh, M., Rowell, F. J. \& Smith, D. S. (1982) Ther. Drug. Monit. 4, 397-403.

10. Sidki, A. M., Al-Abdulla, I. H. \& Rowell, F. J. (1987) Clin. Chem. 33, 463-467.
The only other cross-reacting compounds were 2-en and 4-en valproic acid suggesting that some antibody populations cannot distinguish between unsaturated and saturated compounds. The 4-en compound is the more immunoreactive probably because of the relative positions of the carbon-carbon double bonds. However these cross-reactants will not interfere with the assay of patients' samples since the plasma concentrations of all the metabolites are considerably lower than those of the parent drug (16). This is shown by the correlation coefficient $(r)$ of 0.99 obtained when the results of the immunoassay are compared with those of the gas-chromatography method.

All other reliability criteria of the assay are satisfactory and the small volume $(0.5 \mu l)$ required provides another advantage when limited sample volumes are available especially in paediatric practice.

11. Heide, K. \& Schwick, H. G. (1978) In: Handbook of Experimental Immunology, 3rd edn. (Weir, D. M., ed.) pp. 7.1-7.11, Blackwell Scientific Publications, Oxford.

12. Dimitriadis, G. J. (1979) Anal. Chem. 98, 445-451.

13. Rodbard, D. (1978) Anal. Biochem. 90, 1-12.

14. Raab, G. (1983) In: Immunoassays for Clinical Chemistry, 2nd edn. (Hunter, W. M. \& Corrie, J. E. T., eds.) pp. 614623, Churchill Livingstone, New York.

15. Davis, S. E., Munson, P. J., Jaffe, M. L. \& Rodbard, D. (1980) J. Immunoassay $1,15-25$.

16. Loscher, W. (1981) Epilepsia 22, 169-178.

17. Abraham, G. E. (1969) J. Clin. Endocrinol. 29, 866-870.

18. Hansel, M. C., Rowell, F. J., Landon, J. \& Sidki, A. M. (1986) Ann. Clin. Biochem. 23, 596-602.

19. Cornbleet, P. J. \& Gochman, N. (1979) Clin. Chem. 25, 432-438.

Dr. A. M. Sidki

Department of Chemical Pathology

51-53 Bartholomew Close

St. Bartholomew's Hospital

London EC1A 7HL

U.K. 